\title{
Insight on Excoecaria agallocha: An Overview
}

\section{Satyavani Kaliamurthi* and Gurudeeban Selvaraj}

Centre of Advanced Study in Marine Biology, Annamalai University, Tamil Nadu, India

\begin{abstract}
Excoecaria agallocha is a milky mangrove widely distributed in Indian coastal regions. This review article explains chemical composition, pharmaceutical and environmental applications of $E$. agallocha. There are 20 different polyphenols, 15 terpenoids and more than 50 volatile derivatives were identified from leaves, stem, latex and root extract. Enormous number of compounds isolated from ethanolic extact of leaves. In conclusion, E. agallocha has huge amount of polyphenols and terpenoids, which was reported to have endocrine, epidemic and endemic disease control as anti-microbial, anti-cancer and anti-diabetic agent.
\end{abstract}

Keywords: Mangroves; Thillai; Terpenoids; Rutin; Antidiabetic

\section{Background}

A mangrove is a tree, shrub, palm or ground fern, generally exceeding one half meter in height, that normally grows above mean sea level in the intertidal zone of marine coastal environments and estuarine margins. The term "Mangroves", plants which exist in muddy, wet soil in tropical or subtropical tidal waters. Excoecaria agallocha L. (Euphorbiaceae) is an ancient mangrove species specified in "Thillai Lord Nataraja" temple, Chidambaram as "Tala virucham" in tamil. Common name of Excoecaria agallocha: Agallocha, blinding tree (General name); Thillai, Kampetti (in Tamil); Tilla, Tella and Chilla (in Telugu); Thelakiriya, Thalia (in Singhalese) It is widely distributed abundant in Pichavaram mangrove forest, Indian coastal regions, Australia from northern New South Wales, along the northern coastline around to Western Australia. According to Red list criteria it is a least concern position [1] (Systematic classification) (Figure 1).

\section{Morphological characters identification}

Habit - A dioecious tree to $15 \mathrm{~m}$ high with abundant white latex; Habitat - An evergreen shrub common along with higher estuarine banks, cannels, tidal forest and mangrove swamps; Stem-bark grayish, lenticellate; Roots- Lateral roots spreading and intermingled with each other, supraterranean bandsproduce elbow-shaped pegs instead of pneumatophores; Leaves - leaves alternate, ovate-elliptic or orbicular, apex shortly acuminate, base narrowed, margin entire or sinuatecrenate, 3-8 $\times 1.5-3 \mathrm{~cm}$, glabrous, petiolate; Flowers - Unisexual, Male flowers in catkin spikes, fragrant, yellow, 2-3 mm across; stamens 3 , filaments free. Female flowers in axillary raceme, pale green, 2.5-3.5 $\mathrm{mm}$ across, pedicellate; calyx 3-lobed; ovary 3-celled, trifid style; Fruit - Capsule, globose 3-lobed, seeds sub-globose; Reproductive -Flowers are pollinated by insects; Regeneration - Epigeal or modified epigeal germination [2]. This evergreen mangrove species has traditionally been used to treat sores and stings from marine creatures, and ulcers, as a purgative and an emetic, and the smoke from the bark to treat leprosy [3]. They are well-known as extreme skin irritants and tumor promoter [4]. Recent ethanobotanical survey on Kodiyampalayam coastal village, Nagapattinam district, tamil nadu, India depicted the presence and traditional usage of E. agallocha to blood glucose level reduction and fish poison [5].

\section{Therapeutic Applications}

\section{Impact of Excoecaria agallocha on diabetes mellitus}

Type 2 diabetes mellitus (T2DM), is a prototype multi-factorial complex diseases that considered as one as one of the leading causes of morbidity and mortality around the world [6]. The pancreas plays a primary role in the metabolism of glucose by secreting the hormones insulin and glucagon. The islets of Langerhans secrete insulin and glucagon directly into the blood [7]. When the blood glucose level falls, glucagon secreted and increases blood glucose concentration partly by breaking down stored glycogen in the liver by a glycogenolysis pathway. Also, Gluconeogenesis is the production of glucose in the liver from non-carbohydrate precursors such as glycogenic amino acids [8]. Several studies was elaborated the risk factors responsible for Type 2 DM including obesity, hypertension, smoking, physical inactivity, low education, dietary patterns, family history and specific gene [9]. Recent years, researchers focused their interest to find out the potential anti-diabetic molecules from the medicinal plants to reduce the side effects caused by commercial drugs. Different type of alpha-glucosidase enzyme involved in the absorbtion of carbohydrate molecules such as glucose, sucrose and maltose in to small intestine, which leads to postprandial hyperglycemia. In previous studies we reported the alpha glucosidase inhibitory effect of coastal sand dunes and salt marshes from the southeast coast of India [10]. Alloxan and Streptozotocin is widely used in inducing hyperglycemia than compared to other toxins viz., vacor, 8-hydroxyquinolone dithizone and ferric nitrilo triacetate. The agents can be administered using various methods such as intra-peritoneal, intravenous, or subcutaneous; however, the first route is the most popular in rodents [11]. The $500 \mathrm{mg} / \mathrm{kg}$ body weight of ethanolic extract of E. agallocha exhibited most significant anti- hyperglycemic $(\mathrm{P}<0.001)$ activity in alloxan induced wistar albino mice [12]. Also the $400 \mathrm{mg} / \mathrm{kg}$ body weight of methanolic stem extracts of $E$. agallocha orally administrated in to experimental mice showed significant reduction in serum glucose level $(23 \mathrm{mg} / \mathrm{dl})$ was observed [13]. Overall theantihyperglycemic effect of E. agallocha reflected in a dose dependendent manner. The matrix melltallo-proteinase activity of different extract of E. agallocha confirmed with collagenase and elastase inhibitory action [14]

\section{Impact of Excoecaria agallocha on cancer chemotherapy}

One of the major health issue all around the world is cancer. The major risk factors responsible causes of cancer are tobacco/alcohol consumption, preserved food products, family heredity, environmental

${ }^{*}$ Corresponding author: Dr. K. Satyavani, Centre of Advanced Study in Marine Biology, Faculty of Marine Sciences, Annamalai University, Parangipettai-608 502, Tamil Nadu, India, E-mail: satyavani@ismu.edu.tr

Received February 05, 2016; Accepted February 11, 2016; Published February 18, 2016

Citation: Kaliamurthi S, Selvaraj G (2016) Insight on Excoecaria agallocha: An Overview. Nat Prod Chem Res 4: 203. doi:10.4172/2329-6836.1000203

Copyright: (c) 2016 Kaliamurthi S, et al. This is an open-access article distributed under the terms of the Creative Commons Attribution License, which permits unrestricted use, distribution, and reproduction in any medium, provided the original author and source are credited. 


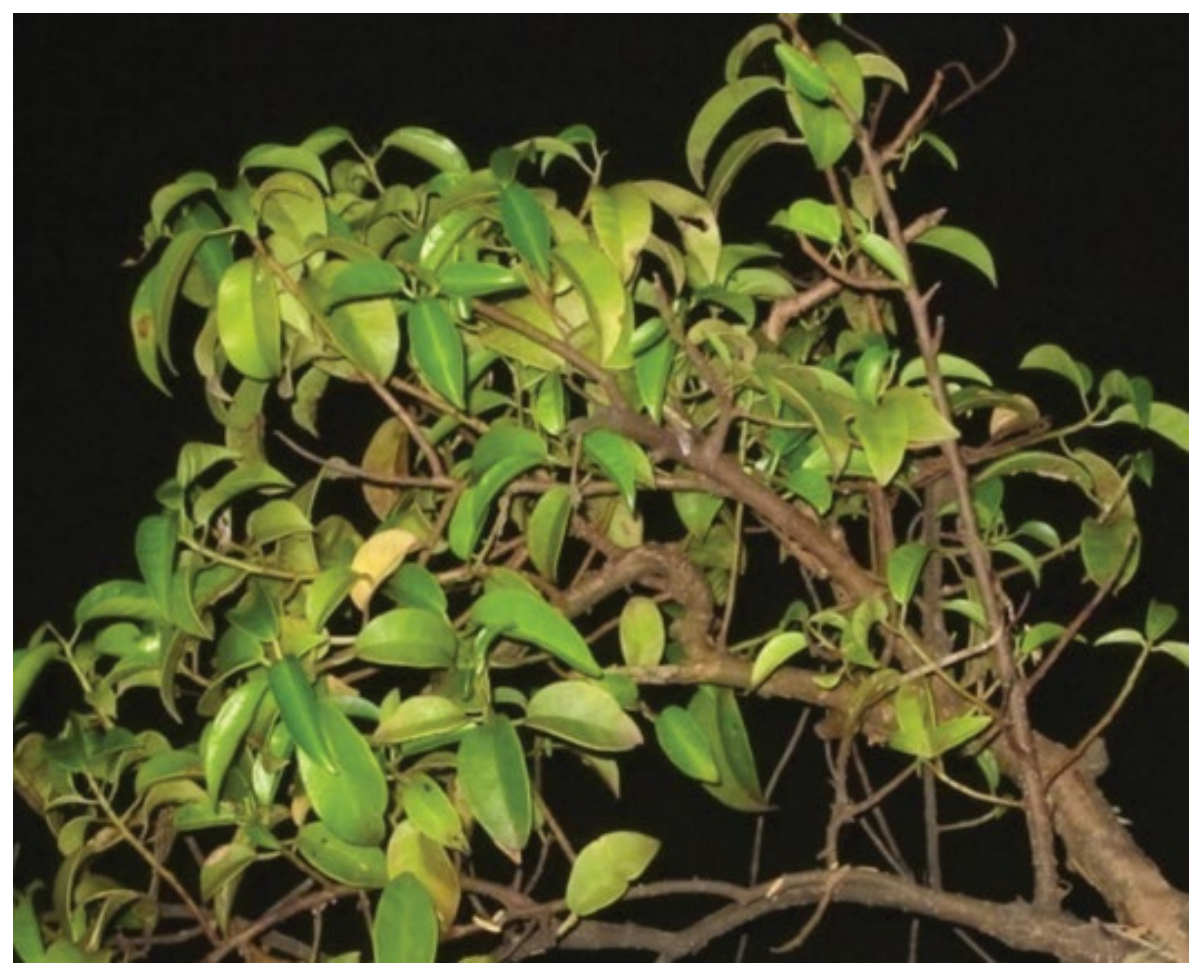

Figure 1: Excoecaria agallocha.

pollution, sexual behaviour, medicines and its treatment procedures. Then compared to other factors, alchol consumption increases the occurance of cancer at oral, oesophagus, pharynx, stomach and liver region respectively. In India, the breast and cervical cancer are predominantly identified in women [15]. Cancer is the second leading disease factor cause more death in United states of America. Siegel et al. [16] estimated the death rate and various cancer sites (Oral cavity and pharynx, Digestive system, Respiratory system, Bones and joint, skin, breast, urinary system, eye, brain, endocrine system, lymphoma, myeloma) in both male and female subjects in United states of America.

Ethanolic stem extract of E. agallocha has an significant cytotoxic effect of different cell lines Miapaca-2, BxPC-3, PANC-1 and Capan-1, IC50 values were higher $(0.11 \mu \mathrm{g} / \mathrm{ml})$ compared with the positive control flavopiridol by MTS assay. It might be action of cardiac glycosides and saponin in the bioactive fraction of E. agallocha confiremed by chromatographic finger printing [17]. The higher concentration of methanolic and chloroform extracts of E. agallocha leaves showed lowest Hep- 2 cells viability of 22 and $8 \%$ under in vitro conditions. Konoshima et al. [18] reported the diterpenoids isolated from E. agallocha wood showed their inhibitory action aganist induction of Epstein-Barr virus early antigen (EBV-EA) in Raji cells under in vitro conditions. Among these, the secolabdane-type diterpenoid showed anti-tumour promoting effect which analysed by in vivo Two-Stage Mouse Skin Carcinogenesis Test with promoter (12-O-tetradecanoylphorbol13acetate) and an initiator 7,12-dimethylbenz[a] anthracene. The Flavonol glycosides of E. agallocha blocked the action of GLI-related protein is a transcriptional effector involved in tumour development which results inhibits the translocation of GLI1 in to nucleus. Therefore, it act as effective Hedgehog signaling inhibitor in cancer therapy $[19,20]$. Norhanom and Yadav [21] reported the long term continous usage of the Euphorbiaceae family species like E. agallocha among rural Malays cause Epstein barr virus associated non-Hodgkin malignant lymphoma. Biotoxicity of E. agallocha reported by Kathiresan and Thangam [22].

\section{Impact of Excoecaria agallocha on pathogenic microbial strains}

Mangrove floral species playes vital role in prevention of soil erosion, act as a sink for enormous amount of active metabolities. Apart from that, the mangroves serve as ahost for many endophytes which include parasitic, faculatative saprobic, actinomycetes and majority of bacterial and fungal species. Especially in E. agallocha, ascomycete geneus Phomopsis species belongs to diaportnaceae family and endophytic bacteria was identified [23]. The endophytes secreted Bacteriocins are act as promising antimicrobial agent [24]. The methanol, hexane and chloroform leaf extracts of E. agallocha were subjected to antimicrobial assay followed the standard agar well diffusion method. Nearly $50 \mu \mathrm{l}$ of the samples with $100 \mathrm{mg} / \mathrm{ml}$ concentration was allowing to diffusion under in vitro conditions for $45 \mathrm{~min}$. Among those strains, the ethanolic extract of E. agallocha exhibited potential antibacterial activity against Acremonium strictum, and Pnicellium expansum then compared to others [25]. The chloroform and water extracts from leaves of $E$. agallocha showed potential activity against urinary tract pathogens, antibiotic sensitive ophthalmic bacterial pathogens, antibiotic resistant bacterial strains and fish pathogen [26]. Staphylococcus aureus is a multidrug resistant pathogenic bacterial strain. It showed resistant to commercially available antibiotics such as ceftazidime, gentanicin and kanamycin. Abeysinghe [27] reported the active ethyl acetate fractions from E. agallocha leaves showed highest inhibition to Staphylococcus aureus than Proteus sp. in the mean time the ethanolic extracts of $E$. agallocha pronounced for significant anti-bacterial activity aganist Staphylococcus aureus, Shigella dysenteriae, Shigella sonnei and Enterococci bacterial strains [28]. Also the methanolic, chloroform and DMSO extract of E. agallocha showed higer zone of inhibition 
aganist the soil born Fusarium udum fungal strains which cause wilt diseases on plants. The minimium zone of inhibition was absorved in Rhizactonia solani and Sclerotium roysii strains on potato dextrose agar medium [29]. Chryseobacterium spp. is a fish pathogen which resistant to commercial antibiotics such as erythromycin, tetracyclines and chloramphenicol [30]. Those antibiotics used in the fisheres sectors to control the infectious diseseases caused by the fish pathogens. The $500 \mathrm{mg} / \mathrm{ml}$ of methanolic extracts of E. agallocha showed the highest inhibition zone to Chryseobacterium gleum by disc diffusion and agar well diffusion assay. It also showed minimum values of minimum bactericidal concentrations and the minimum inhibitory concentration against the Flavobacterium indicum, Chryseobacterium indologenes, Chryseobacterium gleum and Elizabeth kingiameningoseptica [31]. Additionaly, the ethanolic extract of E. agallocha showed higher inhibition to the fish pathogen Aeromonas hydrophila, which is a gram negative free living ubiquotus bacterial strain causes motile aeromonad septicaemia diseases [32]. Agoramoorthy et al. [33] reported the Fatty acid methyl esters extracts (FAME) from leaves of E. agallocha showed significant anti-bacterial and anti-fungal activity aganist Bacillus subtilis, Bacillus pumilus, Candida albicans, Candida krusei, Candida parapsilosis, Candida tropicalis, Escherichia coli, Pseudomonas aeruginosa, Klebsiella pneumonia, Micrococcus luteus and Staphylococcus aureus.

\section{Impact of Excoecaria agallocha on mosquito borne diseses}

Mosquitos borne diseses are dangerous which causes endangered disease like malaria, dengue, filariasis and chikungunya were caused by the mosquito anthropods [34]. Guha-Spair and Schimme [35] reported the mooquito borne diseases causes two million infections, hemorrhagic fever, shock syndrome, impaired action of central nervous system and approximately 12,000 death rate per year. Aedes aegypti is a endemic viral species occurance in the Southeast Asia, Africa including West africa, America and Pacific islands causes dengue fever [36]. Group of researchers evaluated the larvicidal activity of methanol, ethanol, hexane, chloroform and aqueous extracts of E. agallocha aerial parts. However the methanol extract exhibited significant inhibitory concentration aganist Aedes aegypti and Culex quinquefasciatus mosquito larvaes $[37,38]$. Secondary metabolities such as chrysoeriol and 4', 5', 7- trithydroxy 3',5- dimethoxy flavones reported the highest LD50 values and mortality against Mosquito Larvae [39]. Interestingly, the methanolic extracts of E. agallocha showed inhibition to developmental stages of female filarial worm Setaria digitata which is estimated by trypans blue dye and tunel staining for evaluating the fragmentation of chromosomal DNA [40].

\section{Impact of Excoecaria agallocha on pandemic diseses}

Acquired immunodeficiency syndrome is one the epidemic disease cused by the human immunodeficiency virus. Earlier, the phorphol ester bioactive compound isolated from the leaves and stem of E. agallocha from Northwest Australia reported to have anti-HIV potential [4]. Recently, Patil et al. [17] and his co-workers reported the reverse transciptase (RT) enzyme inhibited by active stem ethanolic fraction of E. agallocha which is necessary for the synthesis of proviral DNA. The extract of E. agallocha showed $33 \%$ of iinhibition than compared with the standard drug azidothymidine (35\%).

\section{Impact of Excoecaria agallocha on anti-oxidant and free radical scavenging efficiency}

Cellular damage by free radicals causes a change of the net charge of cells, thus modifying their osmotic pressure and inducing their swelling and their death. The free radicals act also on the mediators of the inflammatory diseases and accelerate the tissue damage. Moreover, cells lesions lead to an increase in the production of the ROS which induces the consumption and depletion of the endogenous chelating agents. The hydroalcoholic extract of E. agallcha exhibitied significant 2,2diphenyl-1-picrylhydrazyl (IC50 $179.16 \mu \mathrm{g} / \mathrm{ml}$ ), hydrogen peroxide (IC50 $120.24 \mu \mathrm{g} / \mathrm{ml}$ ) and nitric oxide (IC50 $134.29 \mu \mathrm{g} / \mathrm{ml}$ ) free radical scavenging activity respectively [28]. Additionly the the lower concentration of alkaloid rich fractions $(10 \mathrm{ppm})$ of E. agallocha exhibited significant $88 \%$ of DPPH free radical scavenging activity [41].

\section{Impact of Excoecaria agallocha on anti-nociceptive effect}

The drug or compounds have the capacity to reduce the sensation of pain is called anti-nociceptive agents. Somatic/visceral and acute/ chronical is the major classification of pain. Also it has been called as neuropathic or inflammatory pain. However the clinical veterinarians and researchers first understand the nociceptive nad antinociceptive pathways which involved in the pathophysiology process of pain [42]. Commerically available non sterodisl anti-inflammatory or anti-nociceptive drugs causes few side effects includes gastric lesions induction in patients. The alkaline chloroform fraction of E. agallocha at $10,15,20$ or $25 \mathrm{mg} / \mathrm{kg}$ was orally administrated into mice to evaluate its anti-nociceptive effect. The central and peripheral analgesic activity was determined using acetic Acid-induced Writhing and hot plate test. Alkaline chloroform fractions significantly reduced the writhing of mice in a dose dependent manner. Further HPLC-MS of Alk-CF confirmed the Rutin, Quercetin, Mycertin, Kaemferol, Luteolin, and Isorhamnetin might be responsible for its anti-nociceptive activity. In silico computational studies proved the higher binding affinity of rutin to COX-1 and 2 analgesic maker protein receptors [43]. Sodium thiopental-induced sleeping time, Open field, Hole cross and Holeboard test were used to determined the test samples potential on mice/rat behaviour changes such as sleeping time, number of square visited, number of entries through the hole and head dips time by using experimental animals. Oral administration of $200 \mathrm{mg} / \mathrm{kg}$ bw of ethanolic extract of EA revealed significant decline in sleeping time and gross behaviour of mice [28].

\section{Potential of E. agallocha in nanoparticles biosynthesis}

Nanobiotechnology and bionanotechnology are essentially synonyms refer to study materials and manipulated at nanometer scale $\left(10^{-9} \mathrm{~m}\right.$ scale $)$ for various appliactaions [44]. Advantages of silver nanoparticles has been increased every year in the field of opto electronics, bimolecular detection, diagnostics, antimicrobial, cancer treatment and environmental application [45-47]. Monodispersive spherical shaped silver nanoparticles synthesized from the leaf sample of E. agallocha. Transmission electron microscopy determined the nanoparticles were 15 to $45 \mathrm{~nm}$ in size. Phenol and functional group of proteins present in the leaf extracts provide stability to the biosynthesized silver nanoparticles [48]. Crystalline nature of silver nanoparticles observed by X-ray diffraction peak pattern at (111), (200), and (220). $100 \mu \mathrm{l}$ of biologically synthesized nanoparticles has the potential to inhibit the nitrite formation in the reaction mixture compared with catechin standard [49]. Nanoencapsulated rutin from Excoecaria agallocha reported to have significant anti-diabetic and diabetic wound healing activity in streptozotocin induced diabetic rats [50,51].

\section{Impact of Excoecaria agallocha as a heavy metal bioindicator}

Due to industrialization, the ground water and soil content are highly polluted by the heavy metals like Zinc, copper, cadmium etc. A 
huge number of studies are in progress how to scavange or remove the heavy metals from the polluted areas such as chemical and mechanical related industries, tourist area, fish landing and hoarbour respectively. In plant species, the zinc and copper metals played vital role in repiratory enzyme system activation phytohormones biosynthesis, photosynthetic process especially in photo system II and some protein, carbohydrates metabolities biosynthesis [52,53]. However those metals are required in minimal quantity for plant metabolism and biosynthesis process, but few mangrove species have the capacity to accumulate huge amount of heavy metals from the afftect areas. Recently, Chakraborty et al. [54] examined the bioaccumulation of zinc, copper and lead heavy metals in the various part of E. agallocha including leaf, stem and root. They selected the 12 major stations such as Canning, Gosaba, Diamond harbour, nayachar island, kakdwip, chemaguri, sagar south, jambu island, fraser gunge, digha, bali an dbagmara in the north east coast of bay of Bengal and sunderbans indain mangrove ecosystem. As a result of this study, in the root and stem part of E. agallocha showed significant level of dissolved heavy metals and it proved its bioindicator potential.

\section{Chemical composition of E. agallocha}

Mangroves are rich sources of primary and secondary metabollities which are involved in many pharmaceutical and environmental applications. Numerous studies has been undertaken by various group of researchers to find out the pre liminary phytoconstitiuents and phenolic compounds present in different parts of E. agallocha. Previous phytochemical investigation studies of E. agallocha leaves revealed that the presence of diterpenoids, triterpenoids, flavonoids, alkaloids, anthraquinone, phytosterol, fixed oil, tannin, phorbole esters, free amino acids, mucilage, glycosides, carbohydrates, and lignin $[55,56]$. Novel Exoecarin D, E and F diterpenoid from Leaves of E. agallocha and their structure depicted as $3 \alpha, 18$-dihydroxy- $3 \beta, 20$ epoxybeyer-15-ene, (15R,16S)-ent-15,16-epoxybeyeran-3-one and ent-3 $\beta$-hydroxykaur-16-en-2-one using NMR and X-ray analytical techniques [57]. Additionally, 14-taraxeren-3-one, dibutyl phthalate, phaeophytin A, betulin, beta rosasterol, betulinic aicd oleanolic and ursolic acid also identified from EA [58]. Fresh leaves of E. agallocha was extracted with mixture of petroleum ether, diethyl ether and ethanol by Likens-Nickenrson distillation method up to $120 \mathrm{~min}$. The concentracted fractions was analysed by GC-MS, it showed the presence of dodecanediol, L-alanine-4-nitroanilide, benzene methanol, 1,1-diethoxyundecane, hexadecane, Metaraminol, 1,2-benzenediol, tetradecane, hexadecane, benzyl alcohol, benzenemethanol, 4-trifluoroacet benzyl alcohol, L-alanine -4-nitroanilide, alanine, 2,6-Octadiene-4, undecane, Pentanoic acid, hydroxybenzenepropanoic acid, diethyl methylphosphonate, acridine, trifluroacetic acid, triethyl (pentafluorophenyl)silane, Ngainone, N-1-Adanantyl-pmethylbenzalimine, pentachlorophenol, Isohumulone, Octadecanoic acid, decane, diethylphthalate, benzamide, pentanenitrile, diacetate, clivorine and 1,2,5-trimethylphyyole by comparing the spectral data with NBS and IDENT dada base [59]. Latex contains alcohols - exocarol, agalocol, isoagalocol and mannitol; $\beta$-amyrin and its 3 -epimer, $\beta$-amyrenone and cycloartenol. Twigs and bark contain a piscicidal compound which is toxic to Cryzias latipes. The leaf extract of E. agallocha used for rheumatism, paralysis, cutaneous infection and abortificant. Several Preclinical trials carried out on Secondary metabolites of E. agallocha showed its potential as anti-HIV, anticancer, antibacterial, antidiabetic activities and antiviral agent. Alkaloids, carboxylic acid, Flavonoids, phenol, saponin, resins, steroids, tannin and sugars from seeds of E. agallocha exhibited anti-inflammatory and analgesic activity [60]. The crude hexane extraction of dried root of E. agallocha showed the presence of acyclic hydrocarbon and n-triacontane with mosquito larvicidal and insecticidal activity [61]. Other group of researchers found that the phytoconstituents in $E$. agallocha has been increased or decresed in their content with respect to salt availability conditions. The potential chemical structures of $E$. agallocha shown in Figure 2. Jenci and Natarajan [62] observed there was a increasing change in their starch and chlorophyll content of $E$. agallocha with respect to $300 \mathrm{mM}$ sodium chloride and $200 \mathrm{mM}$ of potassium chloride. Dioecious nature of E. agallocha, the male trees are dominant then compared to female. Rao et al. [63] micro propagated the shoots and roots of $E$. agallocha under in vitro conditions using Murashige and Skoog, Woody Plant and a modified medium medium.<smiles>CCCCCOC(=O)c1ccccc1C(=O)OCCCC</smiles>

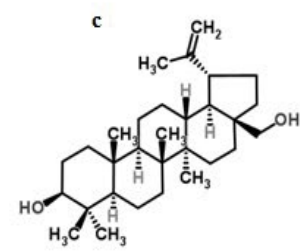

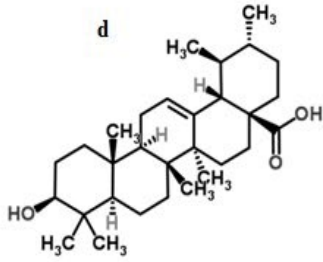<smiles>O=c1c(O)c(-c2ccc(O)cc2)oc2cc(O)cc(O)c12</smiles><smiles>O=C(O)C(F)(F)F</smiles><smiles>Oc1c(Cl)c(Cl)c(Cl)c(Cl)c1Cl</smiles>

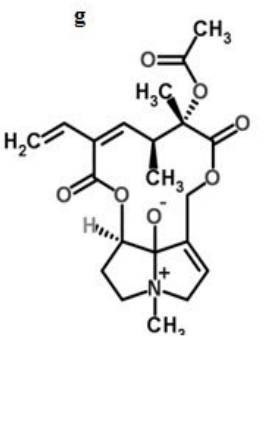<smiles>C[C@H]1O[C@H](CO[C@H]2[C@@H](O)[C@H](O)[C@@H](O)[C@H](O)[C@H]2Oc2c(-c3ccc(O)c(O)c3)oc3cc(O)cc(O)c3c2=O)[C@H](O)[C@@H](O)[C@H]1O</smiles><smiles>O=c1cc(-c2ccc(O)c(O)c2)oc2cc(O)cc(O)c12</smiles><smiles>COc1cc(-c2oc3cc(O)cc(O)c3c(=O)c2O)ccc1O</smiles>

Figure 2: Potential secondary metabolites in E. agallocha (a) Exoecarin D, (b) dibutyl phthalate, (c) phaeophytin A, (d) betulin, (e) Isorhamnetin, (f) trifluroacetic acid, (g) ursolic acid, (h) Rutin, (i) Kaemferol, (j) Luteolin and (k) pentachlorophenol 


\begin{tabular}{|c|c|c|c|}
\hline Source & Active chemical constituents & Nature of extract & Bio activity \\
\hline Leaves & 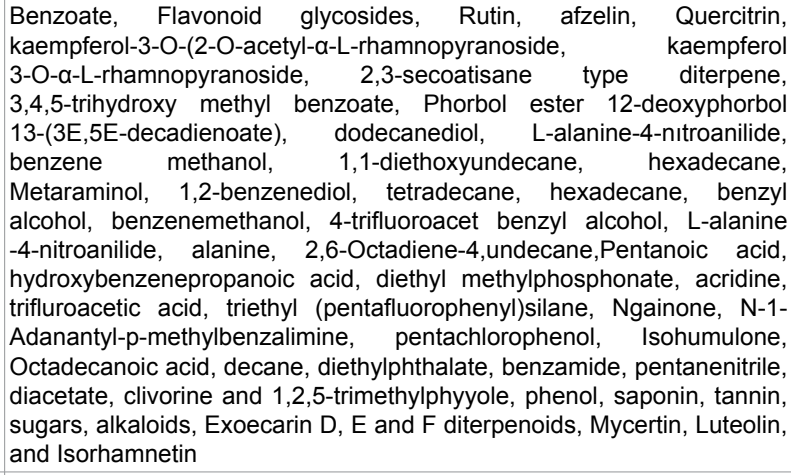 & $\begin{array}{l}\text { Alkaline chloroform fraction, } \\
\text { alkaloid rich fractions, } \\
\text { chloroform extract, DMSO } \\
\text { extract, Ethanolic extract, } \\
\text { Ethyl acetate fractions, Fatty } \\
\text { acid methyl esters, methanolic } \\
\text { extract, methanolic extracts, } \\
\text { water fractions }\end{array}$ & $\begin{array}{l}\text { Analgesic activity, anti-bacterial, anti-cancer, anti- } \\
\text { diabetic, anti-filarial activity, anti-fungal activity } \\
\text { against fish pathogen, urinary tract infections } \\
\text { bacteria and antibiotic sensitive ophthalmic } \\
\text { bacterial pathogens, anti-HIV activity, anti- } \\
\text { inflammatory, anti-nociceptive effect, anti-tumour, } \\
\text { bio accumulation of heavy metal, cytotoxicity, } \\
\text { Diabetic wound healing properties, DPPH free } \\
\text { radical scavenging activity, Nitric oxide free radical } \\
\text { scavenging activity, mosquito larvicidal activity, } \\
\text { silver nanoparticles production }\end{array}$ \\
\hline Bark & $\begin{array}{l}\text { Stachenone, stachenol, excoecariatoxin, daphnane, diterpene } \\
\text { esters,excoecarin }\end{array}$ & $\begin{array}{l}\text { Aqueous extract, ethanolic } \\
\text { extract, hydro alcoholic } \\
\text { extract methanolic extract }\end{array}$ & $\begin{array}{l}\text { Anti-bacterial, mosquito larvicidal activity, pesticidal } \\
\text { and piscicide activity and Neuropharmacological } \\
\text { activity }\end{array}$ \\
\hline Twigs & Stachenol, Stachenone, Excoecariatoxin, daphnane, diterpene esters & & Pesticidal and piscicide activity \\
\hline Stem & Phorbol ester 12-deoxyphorbol 13-(3E,5E-decadienoate) & Ethanolic extract & $\begin{array}{l}\text { Anti-HIV, Reverse transcriptase viral enzyme } \\
\text { inhibition, free radical scavenging activity, Bio } \\
\text { accumulation of heavy metal, insecticidal activity }\end{array}$ \\
\hline Root & Acyclic hydrocarbon, $\mathrm{n}$-triacontane & $\begin{array}{l}\text { Chloroform extracts, hexane } \\
\text { extract }\end{array}$ & $\begin{array}{l}\text { Bio accumulation of heavy metal, anti-bacterial } \\
\text { activity, mosquito larvicidal activity, insecticidal } \\
\text { activity }\end{array}$ \\
\hline Latex & $\begin{array}{l}\text { Agalocol, isoagalocol and mannitol Exocarol, excoecariatoxin, } \\
\text { daphnane diterpene esters, } \beta \text {-amyrin, stachenol, stachenone } 3 \text {-epimer, } \\
\beta \text {-amyrenone, cycloartenol, alkaloids, carboxylic acid, saponin, } \\
\text { xanthoproteins, steroids }\end{array}$ & $\begin{array}{l}\text { Ethanol with water latex } \\
\text { extracts }\end{array}$ & $\begin{array}{l}\text { Causes skin irritation and eye injury, anti- } \\
\text { inflammatory, analgesic activity, Fish poisonous } \\
\text { chemical substance (piscicide). }\end{array}$ \\
\hline Seeds & $\begin{array}{l}\text { Alkaloids, carboxylic acid, Flavonoids, phenol, saponin, resins, steroids, } \\
\text { tannin and sugars }\end{array}$ & $\begin{array}{l}\text { Ethanol with water latex } \\
\text { extracts }\end{array}$ & Anti-inflammatory, analgesic activity \\
\hline
\end{tabular}

Table 1: Chemical constituents and biological activities of Excoecaria agallocha L.

Table 1 indicates the chemical composition and biological activites of E. agallocha. In conclusion, this literature collections provide huge information about the traditional value, therapeutic impacts and phytoconstituents of E. agallocha. However few articles also examined the some toxic effects of E. agallocha latex part. Apart from that, the review shows the promising potential of E. agallocha to develop a drug molecules for epidemic, pandemic and chronic disseses like diabetes mellitus.

\section{Acknowledgements}

The authors wish to thank the authorities of Annamalai University, Tamil Nadu, India for providing all support during the study period.

\section{References}

1. Aleman MS, Bourgeois C, Appeltans W, Vanhoorne B, De Hauwere N, et al. (2010) The Mangrove Reference Database and Herbarium. Plant Ecology and Evoluation 143: 225-232.

2. Kathiresan K, Ramanathan T (1997) Monograph: Medicinal plants of Parangipettai Coast. Annamalai University, Tamil Nadu, India. p: 76.

3. Ghani A (2003) Medicinal Plants of Bangladesh. 2nd edn. The Asiatic Society of Bangladesh 7: 228-229.

4. Erickson KL, Beutler JA, Cardellina JH 2nd, McMahon JB, Newman DJ, et al. (1995) A novel phorbol ester from Excoecaria agallocha. J Nat Prod 58: 769-772.

5. Kaliamurthi S, Selvaraj G, Thirugnanasambandam R (2014) Documentation of hypoglycemic and wound healing plants in Kodiyampalayam coastal village (Southeast coast of India). Journal of Coastal Life Medicine 2: 642-647.

6. Seghrouchni I, Drai J, Bannier E, Rivière J, Calmard P, et al. (2002) Oxidative stress parameters in type I, type II and insulin-treated type 2 diabetes mellitus: insulin treatment efficiency. Clin Chim Acta 321: 89-96.

7. Worthley LIG (2003) The Australian short course on intensive care medicine. Handbook, Gillingham printers, South Australia. pp: 31-55.

8. Sowka JW, Gurwood AS, Kabat AG (2009) Handbook of ocular disease management diabetes mellitus. Review of Optometry. p: 63.

9. Chan JC, Malik V, Jia W, Kadowaki T, Yajnik CS, et al. (2009) Diabetes in Asia epidemiology, risk factors, and pathophysiology. JAMA 301: 2129-2140.

10. Gurudeeban S, Satyavani K, Ramanathan T (2012) Alpha glucosidase inhibitory effect and enzyme kinetics of coastal medicinal plants. Bangladesh Journal of Pharmacology 7: 186-191.

11. Rees DA, Alcolado JC (2005) Animal models of diabetes mellitus. Diabet Med 22: 359-370.

12. Thirumurugan G, Vijayakumar TM, Poovi G, Senthilkumar K, Sivaraman K et al. (2009) Evaluation of antidiabetic activity of Excoecaria agallocha L. in alloxan induced diabetic mice. Journal of Natural Products: 1-5.

13. Rahman M, Siddika A, Bhadra B, Rahman S, Agarwala B, et al. (2010) Antihyperglycemic activity studies on methanol extract of Petrea volubilis $\mathrm{L}$. (Verbenaceae) leaves and Excoecaria agallocha L. (Euphorbiaceae) stems. Advances in Natural and Applied Sciences 4: 361-364.

14. Satyavani K, Gurudeeban S, Ramanathan T (2016) Effect of Excoecaria agallocha $\mathrm{L}$. extracts on elastase and collagenase inhibitory action and identification of metabolites using HPLC-UV-MS. Pharmacetical Chemistry Journal (In press).

15. Nair MK, Varghese C, Swaminathan R (2005) Cancer: Current scenario intervention strategies and projections for 2015. Burden of Disease in India. p: 219.

16. Siegel RL, Miller KD, Jemal A (2015) Cancer statistics, 2015. CA: A cancer journal for clinicians 65: 5-29.

17. Patil RC, Manohar S, Upadhye M, Katchi VI, Rao A, et al. (2012) Anti Reverse Transcriptase and Anticancer activity of stem ethanol extracts of Excoecaria agallocha (Euphorbiaceae). Ceylon Journal of Science (Biological Sciences) 40: 147-155.

18. Konoshima T, Konishi T, Takasaki M, Yamazoe K, Tokuda H (2001) Antitumor-promoting activity of the diterpene from Excoecaria agallocha. II. Biol Pharm Bull 24: 1440-1442.

19. Kinzler KW, Vogelstein B (1990) The GLI gene encodes a nuclear protein which binds specific sequences in the human genome. Mol Cell Biol 10: 634-642. 
20. Rifai Y, Arai MA, Sadhu SK, Ahmed F, Ishibashi M (2011) New Hedgehog/ GLI signaling inhibitors from Excoecaria agallocha. Bioorg Med Chem Lett 21: 718-722.

21. Norhanom AW, Yadav M (1995) Tumour promoter activity in Malaysian Euphorbiaceae. Br J Cancer 71: 776-779.

22. Kathiresan K, Thangam TS (1987) Biotoxicity of Excoecaria agallocha L. latex on marine organisms. Current Science 56: 314-315.

23. Huang Z, Cai X, Shao C, She Z, Xia X, et al. (2008) Chemistry and weak antimicrobial activities of phomopsins produced by mangrove endophytic fungus Phomopsis sp. ZSU-H76. Phytochemistry 69: 1604-1608.

24. Eldeen IM, Effendy MA (2013) Antimicrobial agents from mangrove plants and their endophytes. Microbial pathogens and Strategies for Combating them: Science, Technology and Education. FORMATEX Microbiology Book Series Formatex Research Centre: Badajoz, Spain. pp: 872-882.

25. Vadlapudi V, Bobbarala V, Penumajji S, Naidu KC (2009) Excoecaria agallocha L. antimicrobial properties against important pathogenic microorganisms. International Journal of PharmTech Research 1: 865-867.

26. Raja M, Ravikumar S, Gnanadesigan M, Vijayakumar V (2010) In vitro antibacterial activity of diterpene and benzoxazole derivatives from Excoecaria agallocha L. International Journal of Biological and Chemical Sciences 4: 692-701.

27. Abeysinghe PD (2010) Antibacterial Activity of some Medicinal Mangroves against Antibiotic Resistant Pathogenic Bacteria. Indian J Pharm Sci 72: 167-172.

28. Subhan N, Alam MA, Ahmed F, Shahid IJ, Nahar L, et al. (2008) Bioactivity of Excoecaria agallocha. Revista Brasileira de Farmacognosia 18: 521-526.

29. Kumar P, Ahmed John S (2013) Invitro anti- fungal activity of excoecaria agallocha. I. from pichavaram mangrove forest. International Journal of Plant, Animal and Environmental Sciences 3: 32-34.

30. Hsueh PR, Teng LJ, Yang PC, Ho SW, Hsieh WC, et al. (1997) Increasing incidence of nosocomial Chryseobacterium indologenes infections in Taiwan. Eur J Clin Microbiol Infect Dis 16: 568-574.

31. Laith AA, Najiah M (2014) Antimicrobial activities of blinding tree Excoecaria agallocha against selected bacterial pathogens. Journal of Microbiology and Antimicrobials 6: 29-36.

32. Dhayanithi NB, Ajith Kumar TT, Balasubramanian T (2012) Effect of Excoecaria agallocha leaves against Aeromonas hydrophila in marine ornamental fish, Amphiprion sebae. Indian Journal of Marine Sciences 41: 76.

33. Agoramoorthy G, Chandrasekaran M, Venkatesalu V, Hsu MJ (2007) Antibacterial and antifungal activities of fatty acid methyl esters of the blindyour-eye mangrove from India. Brazilian Journal of Microbiology 38: 739-742.

34. Kamaraj C, Bagavan A, Rahuman AA, Zahir AA, Elango G, et al. (2009) Larvicidal potential of medicinal plant extracts against Anopheles subpictus Grassi and Culex tritaeniorhynchus Giles (Diptera: Culicidae). Parasitol Res 104: 1163-1171

35. Guha-Sapir D, Schimmer B (2005) Dengue fever: new paradigms for a changing epidemiology. Emerg Themes Epidemiol 2: 1

36. Pancharoen C, Kulwichit W, Tantawichien T, Thisyakorn U, Thisyakorn C (2002) Dengue infection: a global concern. J Med Assoc Thai 85 Suppl 1: S25-33.

37. Thirunavukkarasu P, Ramanathan T, Renugadevi G, Jayalakshmi S (2011) Studies on larvicidal potential of Excoecaria agallocha L. bark extract. Journal of Pharmacy Research 4: 3480.

38. Pradeepa P, Subalakshmi K, Saranya A, Dinesh P, Raj VA, et al. ( 2015) Milky Mangrove Excoecaria agallocha $L$. Plant as a source for potential mosquito larvicides. Journal of Applied Pharmaceutical Science 5: 102-105.

39. Raihan SA (2014) Effect of Plant Flavonoids on Mosquito Larvae. Journal of Science 1: 27-30.

40. Patra JK, Mohapatra AD, Rath SK, Dhal NK, Thatoi H (2009) Screening of antioxidant and antifilarial activity of leaf extracts of Excoecaria agallocha $\mathrm{L}$. International Journal of Integrative Biology 7: 9-15.

41. Satyavani K, Gurudeeban S, Ramanathan T, Balasubramanian T (2013) Radical scavenging effect and GCMS identification of alkaloid fractions from Excoecaria agallocha L. Inventi Rapid: Ethnopharmacolology 1: 1-4

42. Lemke KA (2004) Understanding the pathophysiology of perioperative pain Can Vet J 45: 405-413.
43. Selvaraj G, Kaliamurthi S, Thirungnasambandam R, Vivekanandan L, Balasubramanian T (2014) Anti-nociceptive effect in mice of thillai flavonoid rutin. Biomed Environ Sci 27: 295-299.

44. Khademhosseini A, Toner M, Borenstein J, Takayama S (2008) Micro and Nanoenginernig of the cellular microenvironment: Applications and Technologies. Artech House Publishing, USA.

45. Schultz S, Smith D, Mock JJ, Schultz DA (2000) Single-target molecule detection with nonbleaching multicolor optical immunolabels. Proceedings of the National Academy of Sciences 97: 996-1001.

46. Satyavani K, Gurudeeban S, Ramanathan T, Balasubramanian T (2011) Biomedical potential of silver nanoparticles synthesized from calli cells of Citrullus colocynthis (L.) Schrad. Journal of Nanobiotechnology 9: 2-8

47. Satyavani K, Gurudeeban S, Deepak V, Ramanathan T (2013) Heliotropium Curassavicum mediated Silver Nanoparticles for Environmental Application Research Journal of Chemistry and Environmen 17: 27-33.

48. Satyavani K, Gurudeeban S, Ramanathan T (2014) Influence of leaf broth concentration of Excoecaria agallocha as a process variable in silver nanoparticles synthesis. Journal of Nanomedicine Research 1: 1-5.

49. Sangeetha A, Saraswathi U, Singaravelu (2014) Green synthesis of silve nanoparticles using a mangrove Excoecaria agallocha. International Journal of Pharmaceutical Science Invention 3: 54-57.

50. Satyavani K (2013) Nanoencapsulation, Characterization and Ointmen Formulation of Rutin from Excoecaria agallocha L. on control of Type I Diabetes Mellitus and Diabetic Foot Ulcer using Wistar albino rats. PhD Thesis, Annamalai University, India. p: 284.

51. Satyavani K, Ramanathan T, Gurudeeban S, Balasubramanian T (2013) Drug for Treatment of Diabetes and Diabetic Foot Ulcer Using Rutin Loaded Solid Lipid Nanoparticles. Official Journal of Patent Office (India). p: 326.

52. Ernst WHO, Verkleij JAC, Schat H (1992) Metal tolerance in plants. Acta Botanica Neerlandica 41: 229-248.

53. Shaw AJ (1990) Heavy Metal Tolerance in Plants: Evolutionary Aspects. Nordic Journal of Botany 13: 330 .

54. Chakraborty S, Zaman S, Mitra A (2014) Excoecaria agallocha: a potentia bioindicator of heavy metal pollution. International Journal of Engineering Research and General Science 2: 289-298.

55. Zou JH, Dai J, Chen X, Yuan JQ (2006) Pentacyclic triterpenoids from leaves of Excoecaria agallocha. Chem Pharm Bull (Tokyo) 54: 920-921.

56. Deepa M, Padmaja CK (2014) Preliminary phytochemical analysis and thin layer chromatography of the extracts of Excoecaria agallocha L. International Journal of Pharmaceutical Sciences and Research 5: 4535-4542.

57. Konishi T, Konoshima T, Fujiwara Y, Kiyosawa S (2000) Excoecarins D, E, and K from excoecaria agallocha. J Nat Prod 63: 344-346.

58. Xu J, Deng ZW, Lin WH (2009) Chemical constituents of mangrove plant Excoecaria agallocha in Hainan Province. Chinese Traditional Herb Drugs 411: 1704-1707.

59. Satyavani K, Gurudeeban S, Manigandan V, Rajamanickam E, Ramanathan T (2015) Chemical Compositions of Medicinal Mangrove Species Acanthus ilicifolius, Excoecaria agallocha, Rhizophora apiculata and Rhizophora mucronata. Current Research in Chemistry 7: 1 .

60. Babuselvam M, Ravikumar S, Farook KM, Abideen S, Mohamed MP, et al. (2012) Evaluation of anti-inflammatory and analgesic effects on the extracts of different parts of Excoecaria agallocha L. Journal of Applied Pharmaceutical Science 2: 108-112.

61. Satyan RS, Sakthivadivel M, Shankar S, Dinesh MG (2012) Mosquito larvicida activity of linear alkane hydrocarbons from Excoecaria agallocha L. against Culex quinquefasciatus Say. Nat Prod Res 26: 2232-2234.

62. Jenci M, Natarajan S (2009) Growth and organic constituent variations with salinity in Excoecaria agallocha L. an important halophyte. Botany Research International 2: 50-54.

63. Rao CS, Eganathan P, Anand A, Balakrishna P, Reddy TP (1998) Protocol for in vitro propagation of Excoecaria agallocha $L$. a medicinally important mangrove species. Plant Cell Reports 17: 861-865. 